\title{
Study on the Golf Professional Education Curriculum System in Colleges and Universities in China*
}

\author{
Xueyun Shao \\ Golf College Shenzhen University, Guangdong Province, China \\ shaoxy@szu.edu.cn
}

\begin{abstract}
This paper, beginning with the status quo of golf professional education in colleges and universities in our country. Three representatives colleges and universities of golf professional education curriculum system are selected, i.e., Golf College of Shenzhen University (GC-SZU), Shenzhen Tourism Institute of Jinan University (STI-JNU) and Tourism Institute of Guangzhou University (TI-GZU). Those research results of this paper have a positive practical significance on improving the level of golf courses in colleges and universities in our country, as well as promoting the development of China's golf industry.

Index Terms - golf professional education, curriculum system, colleges and universities, China
\end{abstract}

\section{Introduction}

Within 20 years of time, the golf higher education in our country is still in the initial stage of development, Approved by the Shenzhen Municipal People's Government, Golf College was established in Shenzhen University in 1997, with the attribute of the civilian-run and state-subsidized and independent institution legal person qualification. Golf College of Shenzhen University, China's first golf training specialized personnel of higher education institutions, is recognized as the leader of China's Golf higher education. Afterwards, Jinan University, Guangzhou University, South China Normal University, Guangzhou Sports University, South China University of Technology, Zhuhai College of Jilin University have also opened a golf related course, conducting higher education for golf. In face of the current domestic increasing status golf course foundation in colleges and universities, it is necessary to start from the investigation of current situation. This will facilitate to strengthen the curriculum construction, promote the teaching reform, expand golf population in colleges and universities, ensure the quality of teaching and personnel training, and strengthen personnel training positions. As the first batch of professional institutions of domestic higher golf education, it certainly has representative on investigation and study on golf professional education curriculum system of GC-SZU, STI-JNU and TIGZU. Based on the comprehensive literatures studies, curriculum system comparisons, and questionnaire and students' interviews, the author finds out the problems and restricting factors existed in the construction of golf courses in domestic colleges and universities. In addition, in order to meet the demand of high quality professional talent by the rapid development of golf sports in China, the author puts forward the proposal that the present golf professional education course system should be overall optimized based on principles systematicness and adaptability, feasibility and individualization and prominent golf professional characteristics and so on. At the same time, it has positive practical significance on improving the level of golf courses in colleges and universities in our country and also promoting the development of China's golf industry.

\section{Objects and Methods}

A. Objects

In this paper, we take golf professional education curriculum system in Colleges and universities in China as the research object. Meanwhile, the golf professional education curriculum system of GC-SZU, STI-JNU and TI-GZU are selected as investigative objects.

\section{B. Methods}

1) Literature: By reviewing recent years' literature of golf education and reading lots of related scholars' research results which mainly come from the digital library of Shenzhen University and the relevant foreign official website, the author obtained a comprehensive understanding of golf field research and its cutting-edge developments. In order to provide reliable theoretical basis and the detailed information, the author also read related books such as philosophy, society, economy, education and sports.

2) Questionnaire: The investigation started from Nov.10th 2012 and the questionnaires were distributed to 100 students from Shenzhen University, Jinan University and Guangzhou University separately. By Dec.10th, 2012, 290 of them were collected and there were 281 effective ones, and the effective rate retrieve is $93.7 \%$. Reliability of the questionnaire: sample review was made on the questionnaire retrieved, 20 students who have finished the questionnaire were retested, the coefficient of correlation of two questionnaires is 0.934 , and the overall relevance is high.

3) Interview: In the implementation process, the author adjusted the research framework according to the feedback of expert consultation and advice. In order to get the first data, some students are chosen to be interviewed.

\footnotetext{
* This work is partially supported by Foundation for Distinguished Young Talents in Higher Education of Guangdong, China (Grant NO. 2012WYM_0117)
} 
4) Logical analysis: The author obtained macro level of understanding and the related phenomenon by logical reasoning and analysis data or information coming after inspection or survey.

\section{Results and Analysis}

A. Overview of the golf professional education in colleges and universities in China

At present, there are not many colleges and universities with golf professional education, and less than 10,000 undergraduate students in golf major. With the development of golf industry, the lack of high quality management talent has become an important factor restricting the healthy development of China's golf industry. What's more, as an important field of training senior professionals in the golf industry, the specialty of golf sports and management does not exist in Chinese higher education professional directory, it is only a direction of the secondary subject under sports or management professional discipline. So, curriculum system of golf undergraduate education is not perfect, and is always with uncertain subject classification. Moreover, most of the curriculum systems are with ambiguity of talent training mode and goal. So it is concluded that the curriculum, teaching methods and teaching materials are still in their exploratory stage.

Due to the lack of authoritative department statistics, we don't have the total number of specific data of golf professional education in China's colleges and universities, and the exact figures of each level is not accurate. Through the Internet search and literature analysis, there are a total of 40 colleges and universities which has the golf professional in China, except regions like Hong Kong, Macao and Taiwan. They can be divided into two categories, one has undergraduate golf professional, such as Shenzhen University, Jinan University, Beijing Sport University, Shanghai Jiao Tong University, College of Visual Arts of Fudan University, Golf Business School of Tongji University with a total number of 27. The other is to open the golf course in the school, such as Capital Normal University, South China Normal University, Wuhan University, Shanghai University of Finance and Economics, with a total number of 13 .

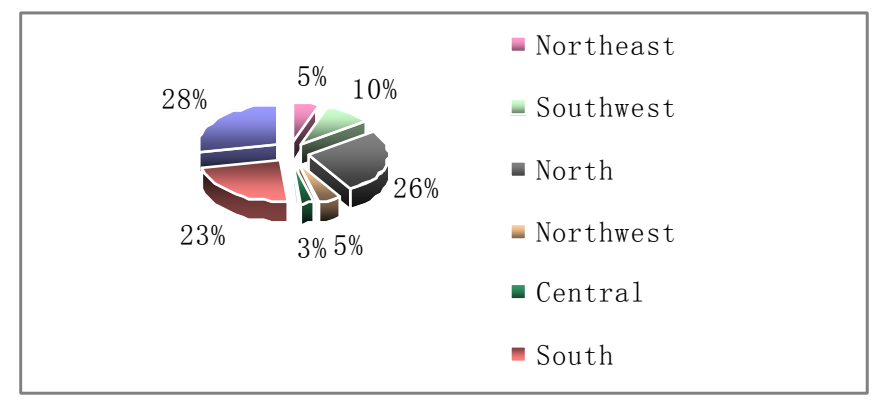

Fig. 1 Regional Distribution of Colleges and Universities having Golf Professional Education
From Fig. 1 we can see that there are regional differences in professional golf course opened in colleges and universities, which mainly concentrate in the East, Southern China and North china. On one hand, these three areas include Shanghai, Guangdong and Beijing three provinces or cities. The number of 18 - hole golf course in Guangdong and Beijing accounted for $18.2 \%$ and $12.2 \%[1]$, separately, the number of golf courses in Shanghai is among the top ten as well, all of which need a lot of golf professional talents. On the other hand, the total round played in Guangdong and Beijing in 2012 were 3.5 millions and 1.45 millions. About 0.6 million rounds played in Shanghai, let it was located in the second echelon. The number of round played can show us the demand by players, indirectly related to the demand for golf service personnel. Undergraduate colleges and universities in Southwest region also accounted for a certain amount. According to incomplete statistics, projects including in construction, renovation and planning to construction in Southwest China accounted for $20.8 \%$ in 2011, the development of golf course are tend to move to this region. In addition, regions like Xinjiang, Tibet still have no golf professional courses.

As stated above, there are 27 of 40 colleges and universities have set up golf professional education, these professional can be classified into three categories: golf industry management, golf turf management and golf skill training. Particularly, golf industry management is dominant among these three categories. According to incomplete statistics, colleges and universities opening the specialty of golf industry management institutions accounts for 58.3\%, while those colleges open the major of golf skill training reaches $25 \%$, and universities open the professional of golf professional institutions account for $16.7 \%$ (see Table 1). These three categories are affiliated in different colleges or department, such as golf management under Tourism College or Business Administration. In addition, most colleges have taken the mode of cooperating with international institutions to train talent, some of which with oversea golf professional institutions and some with Golf Professional Association like PGA. Due to data and time limitations, this paper chooses the representative colleges and universities -- Shenzhen University, Jinan University, and Guangzhou University as research objects.

\section{B. Current situation of golf professional education curriculum systems in colleges and universities in China \\ 1) About the teachers}

According to the result of literatures, questionnaire, and interview, we can see that golf coaches in these three colleges and universities are fewer in number, Shenzhen University has the most, which is 5 , and the other two universities have only 3 people to teach skill.

The reasons are: firstly, the golf itself belongs to a high consumption of sports, so the relevant course also belongs to the high cost of subjects. Skills training are not a compulsory course when setting up in universities, so students with good family conditions and have a strong interest in the game will 
take this high costing game; secondly, the development of golf in China is still relatively weak, so domestic professional golf coaches resources in a serious lack of situation. By the end of 2012, about 3000 coaches have passed relevant qualification examination organized by China Golf Association (CGA) and obtained CGA Coach Certification, including about 300 of intermediate level, 43 of national level, which only passed theory test, but haven't taken 4 consecutive days of technical examination shooting within 80 . However, there are 477 golf courses now in China in 2012. So it is easier said than done to recruit high level professional coach. And the cost of inviting overseas professional golf coaches is too high, which leads to the imbalance golf coaches' demand in recent years.

TABLE 1 Direction of Golf Professional Education in Colleges and Universities in China

\begin{tabular}{cccc}
\hline & \multicolumn{3}{c}{ Direction of Golf Professional Education } \\
Direction & Golf industry & Golf turf & Golf skill \\
& management & management & training \\
Proportion & $58.3 \%$ & $25 \%$ & $16.7 \%$ \\
\hline
\end{tabular}

From the academic structure, teachers equipped in three colleges have high education background and qualifications. However, because of a short time of golf development in China, so the golf teaching still at the exploration stage and the majority of golf coaches need to enhance themselves all the time. So it needs to combine with students' learning then sums up the most suitable teaching program. Some golf courses in Colleges and universities are used as tourism professional courses, with the main purpose of meeting social development demand in the tourism market. However, those courses don't cultivate professional golf coaches or athletes [2], which leads to teachers' overall lower professional requirements level.

Secondly, the number of teachers is still relatively small. It is a common phenomenon for one teacher to take several courses at the same time. Teachers generally have short age or taking golf professional courses, because this course opened much more late than other sports such as table tennis, basketball, football and other high populated courses. Combining with the background of higher physical education in China, i.e. sports academies in China generally do not set the specialty of golf. We can see professional talent training is almost blank. Therefore, this requires the golf professional teachers have certain ability of self-study, update themselves in teaching, acceptance of new knowledge and new skills.

Abundant teaches is an important guarantee for cultivating excellent students, but the problems of weak in teachers is a difficult problem to solve in the short term. As a new educational entity, no one involves in golf education in the domestic education. So it has a serious shortage of teachers. Facing the reality of China's golf, there is no experience for reference in development direction, education curriculum set up, teaching material construction, overall teaching theory, and teaching methods. We only go across the river by feeling the stones. Because most of the teachers are basically stepped in halfway, they are not only lack of the golf professional education, but also in shortage of practical experience. From these points one can imagine the difficulty of teaching. At the same time, because teachers are lack of handson experience, it is difficult to improve the teaching quality of many curriculum strongly requiring closely linked with the actual application. Let's take the course of How to conduct a competition as an example on golf courses organization. Because most teachers do not have the opportunity to personally involved in the operation of events, so they have little understanding on the entire event process required such as the event planning, publicity, the assignment of personnel and organization, requirements of course and et al. That leads to they only choose some strong theoretical knowledge as curriculum content, focuses on a general introduction when teaching event organization, such as some famous tournament in the world. Because of the scarcity of teacher resource, it always results in many teachers need to teach a number of divisions, which relatively requires teachers to spend more energy to prepare for these different courses, and thus affected the quality of curriculum in the end. Shortage of teacher's resources often leads to a series of curriculum problems like teaching contents are not connected with practice.

\section{2) About the use of teaching content and teaching materials}

In these three universities, although golf courses are different, there are still great generalities, all of which have courses like: golf competitions and Rules, golf course design and construction, golf turf management, golf club management, golf marketing, introduction to golf and golf skill. This shows that universities with golf professional education pays great attention to golf turf and project management related courses. Based on the practical investigation and interview, it shows that different colleges have different opinions on their core courses. Shenzhen University focuses on golf industry management, while Jinan University and Guangzhou University take turf management as the core of golf course. In these two universities, such courses will be offered as long as condition is sufficient, what's more specific laboratory and field will be provided, e.g. GC-SZU have independent lawn experimental base and laboratory, letting the students apply to the practical operation besides learning golf turf management theory knowledge in the classroom, hence improve the students' understanding of the curriculum and the actual operation ability. But for the skill course, the three universities take them as elective subjects, with no specific requirements and standard for students.

In addition, the Jinan University also opened caddie management course. Caddy is the most precious resources in club management. Offering course like caddie management can help the students forms a deeper understanding of the special group of caddy. How to manage caddy is one of the most important factors in the club management. Finally it becomes qualified golf management personnel. Besides golf caddie training courses, Guangzhou University also offers second foreign language (Japanese) course. It shows that more and more Japanese and South Korean players will choose to play in China. Such second foreign language course let 
students not only have a good master of English, but also grasp another language. They can communicate with guest better, helps to increase the students' competition advantage in future employment.

The textbook is the foundation of transforming course objectives prescribed by teaching plan and teaching outline into students' specific learning form in the classroom[3]. If there are no good teaching materials, macro curriculum goal will lose its support, personnel training objectives could not be achieved. Three universities pay too much attention to club management (the so-called golf management). They have general training mode and want to develop a versatile, but often results in not good at the subdivision courses. Coupled with the lack of necessary research and professional construction personnel and facilities, arbitrariness is large in golf professional education theory teaching and practice teaching. The setup of professional curriculum is lack of scientific and systematic, often opened with the university's specific circumstances, rather than from the rationally system of professional teaching. Meanwhile, the content of the courses are widely, but most of which are vague, poorly in application and operational of knowledge. With large curriculum capacity but less amount of information, the courses often focus on principle knowledge introduction, such as function and role.

\section{3) About the software and hardware facilities in university}

Besides sitting in the classroom, students' understanding of golf professional knowledge can also obtained and better grasped by attending lectures or research off-campus golf professionals. Although 18 years' golf education development in our country has made certain achievements, it is still in the initial stage with low overall level and serious lack of domestic golf professional talents. It will lead to the cooperation between school golf professional exploration and enterprise or golf association a mere formality.

In the questionnaire, when asking about the students whether the college arrange insiders or well-known scholars to give lecture or conduct research in the normal class period, $70 \%$ of the students from Shenzhen University take the answer of "yes, but a few". $65 \%$ Jinan University's students also said "yes, but a few". 53\% of the students at Guangzhou University said 'yes, but a few', about $37 \%$ of the students even said "never" (Fig. 2). We understand that three college students will be very interested in professional forum organized by universities from interviewing with the students. Most of the students said that because it's not his intention to choose the golf major originally, so largely of them knows nothing about golf before they enter into college. Participating in these lectures can not only help students understand golf from outside the classroom, can also give them the opportunity to get to know celebrities from China's golf Industry other than from education. It can greatly increase their interests on golf.

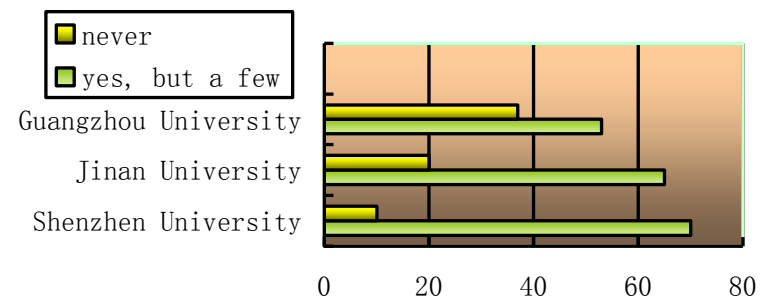

Fig. 2 Survey to Lecture given by Well-known or Scholars from Industry

In addition to provide students opportunities attending lectures or research, the school also can enrich students' understanding of golf through other means.

Such as the GC-SZU cooperate with Mission Hills that student's service in World Cup and WGC-HSBC Champions as volunteers. Participating in such golf competition further enhance the students' understanding professional knowledge of course design, event process and operation, and cultivate good foreign language communication skills and hard-working spirit.

\section{Conclusion}

At present, there are 40 colleges and universities with golf professional education, and less than 10,000 undergraduate students in golf major. Regional differences exist in professional golf course opened in colleges and universities, which mainly concentrate in the East, Southern China and North china. The problem of weak in teachers is a difficult issue to solve in the short term. Shortage of teacher's resources often leads to a series of curriculum problems like teaching contents are not connected with practice. Most of universities pay too much attention to club management, using general training mode, which often results in not good at the subdivision courses. Golf professional education is still in the initial stage with low overall level and serious lack of domestic golf professional talents, which will lead to the cooperation between school golf professional exploration and enterprise or golf association a mere formality. It is lack of system training mode, and thus teaching effect can not reach the expected goal.

\section{Acknowledgment}

This research was financially supported by Foundation for Distinguished Young Talents in Higher Education of Guangdong, China (Grant NO. 2012WYM_0117).

\section{References}

[1] Forward Group, “White Paper of Forward Group”, Report on China Golf Industry2012, 2013.

[2] Zuqing Lan, Tianrui Ma, "Discussion on the dilemma faced by golf professional education in China," Journal of Education, vol. 19 pp.66 67, 2012.

[3] Xueyun Shao, Xiaochun Zhang and Xiaorong Chen, "Research on Golf Education in China: Its Significance, Characteristics and Future," Lecture Notes in Intelligent Information Technology Application, Springer, vol.109, pp. 905-911,2011. 